\title{
Adaptive Capacity of Brantas Watershed in Malang City Fancing of the Climate Change Impact
}

\author{
Dwi Prihanto ${ }^{1}$, Arief Rachmansyah², Harsuko Riniwati ${ }^{3}$ \\ ${ }^{1}$ Master Program of Environmental Resources Management and Development, Brawijaya University \\ ${ }^{2}$ Civil Engineering Department, Engineering Faculty, Brawijaya University \\ ${ }^{3}$ Program of Agribusiness Fisheries, Fisheries and Marine Science Faculty, Brawijaya University
}

\begin{abstract}
The impact on global warming is the occurrence of climate change that affect the condition of watershed ecosystem (DAS). This condition causes a decline in the level of community welfare and increases the level of community vulnerability. Furthermore, these ecological changes may have an effect on the adaptive capacity of community living in the watershed area. This paper raised the issue of climate change that occurred in the Brantas watershed society of Malang city. Adaptive capacity has an important role in addressing and minimizing vulnerability in an area. This study aims to analyze the level of adaptive capacity community on climate change. This type of research is classified as a quantitative descriptive where data acquisition and processing are derived from secondary data of regional device organization classified into several parameters and indicators then processed using weighted scale and displayed in spatial maps. This paper shows that the phenomenon of climate change has been significantly felt by the people living in the Brantas watershed. Nevertheless, these symptoms have not been considered a significant problem by the community. This is influenced by limited knowledge of the symptoms of climate change. Other findings show that adaptive capacity is not only determined by environmental conditions. The social structure of both patron-client and institutional relationships at the village level is very influential on the adaptive capacity of the Brantas watershed of Malang city.
\end{abstract}

Keywords: Adaptive capacity, Brantas watershed, Climate change, Malang city, GIS, Social structur

\section{INTRODUCTION}

Global warming is a problem that humanity must face now and no longer a problem of the future.This incident is the long-term accumulation of atmospheric pollution caused by human activity that causes the release of greenhouse gases into the atmosphere at a very high rate which then impacts on climate change.

Climate phenomena such as floods, long droughts, strong winds have been felt increasingly occurring lately with high intensity As a result, the impact is increasingly greater with the high level of environmental damage. [1]

Show that based on the results of the search for the International Disaster Database database ,of natural disasters that enter into the global disaster category as many as 345 disasters. [2]

About $60 \%$ of these natural disasters are natural disasters due to extreme climates such as floods, droughts, forest fires, strong winds/storms, landslides, high tides and outbreaks of disease. Climate change based on

Correspondence address:

Dwi Prihanto

Email : prihanto_dwi68@yahoo.co.id

Address : Post Graduate School of Environmental and Developmen, Graduate Program, Brawijaya University, Malang, Indonesia the definition of the Ministry of Environment that is changing the physical condition of the earth's atmosphere, among others, temperature and distribution of rainfall that bring widespread impact on various sectors of human life. [3]

As a result of climate change related to human life, that is, a temperature rise of up to $3^{\circ}$ $\mathrm{C}$ over the last hundred years has affected the food and water ecosystem, increasing precipitation in high latitudes. Brantas watershed degradation of Malang City cause ecosystem can not optimal provide function and service which is very important for human life. These events led to decrease in the level of community welfare and increased levels of community vulnerability. Community vulnerability is a condition of society that can not adapt to ecosystem changes caused by a particular threat [4].

Brantas watershed upstream is the catchment area for rainwater toward the river that flows into Batu and Malang City with Malang district. Damage to the Brantas watershed area may result in flooding in Malang city.Brantas watershed as a catchment area becomes a source of water supply for some areas that it runs like Jombang, Mojokerto, Surabaya and Sidoarjo. Brantas watershed that runs across the administrative area of Batu, Malang and district 
(upstream) and Sidoarjo district (downstream) into a unified system that must be managed in an integrated and comprehensive from upstream to downstream. [4].

Meanwhile, if in watershed management practices and land use practices are not done in an integrated and unplanned manner, it affects the occurrence of erosion and sedimentation. The shifting of seasons in the Brantas watershed area has caused in agricultural activities by the community. [5].

Agriculture that relies on water supply from the Brantas watershed is less effective and unprofitable. Unpredictable climate Phenomenon is also one of the reasons farming is unproductive. Water production at some point has decreased and even disappeared. While the number of dangerous and vulnerable areas has increased. [5].

Likewise, landslides have increased in the past 2 years. Brantas watershet Degradation is increasingly critical to cause the watershed is not optimal to provide functions and services for the community. Upper Brantas watershed as buffer zone, water catchment area, water filter, and carbon absorb will be damaged. As a consequence Malang city will lose water supply and in rainy season will cause flood. [5].

In a matter of years, Brantas watershed area of Malang city will become critical. Sensitive community will be more vulnerable, while adaptable people will survive. Based on these conditions, there needs to be a study in looking at the extent of the adaptive capacity of the community to climate change in the Brantas watershed of Malang city. [6].

So through this study can be known the level of adaptive capacity of people in the Brantas watershed area of Malang City with the base of the village through several indicators. The final outcome of this study bring up the conclusions and recommendations of any region whichever the level of adaptive capacity is low, so that it can be an input or idea for urban area development planning that is adjacent to the watershed area (DAS). [6].

\section{RESEARCH METHODS}

The research method used is quantitative to analyze this research, where the data obtained from the OPD or institution regional and research focus on the vulnerability of society in Brantas watershed area of Malang City which there are 4 sub-districts consisting of 11 village. Data processing from each village data is compared with the total area of study/city scale so that the range of values between 1-5, where each determined its weight to then be displayed in spatial map. [7].

And finally it can be clearly known which areas are not vulnerable, vulnerable and highly vulnerable to physical parameters (area, historical floods and landslides, elevation, rainfall, number of health facilities (physicians), number of posyandu facilities, EWS, availability of evacuation stages, number of buildings in river border and drinking water access from the study area. [8].

\section{Method of collecting data}

Data collection methods in this study use secondary data where data obtained from various agencies such as Barenlitbang, BPBD, DLH (environmental services), PODES, Indonesian Disaster Risk Index and several other agencies involved. The comparison data shows up to village data. The data result from OPD or institution as follows:

Table 1. Data Research and Proceesing

\begin{tabular}{cll}
\hline No & \multicolumn{1}{c}{ Data } & \multicolumn{1}{c}{ Data Optained } \\
\hline 1 & Total Doctor & Health Departement \\
2 & Total Infrastucture & Health Departement \\
3 & Total volunteers & BPBD \\
4 & Total UMKM & Trading Department \\
5 & individuals who work & Manpower Departmen \\
6 & Total EWS & BPBD \\
7 & Evacuation route & BPBD \\
Source: Secondary data obtained. [7],[8], [9].
\end{tabular}

Then the process of collecting primary data is done through AHP (Analytical Hierarchy Process) quisioner activities that are distributed to cadre and volunteers disaster formed by BPBD (disaster agency) Malang City scattered in each village.The goal is to obtain precise and accurate inform ation from the required data.

The method is done by using a quisioner that contains questions related to understanding the actual condition of the actual Methods performed using the AHP quisioner.

\section{RESULTS AND DISCUSSION}

Adaptive capacity is defined as the ability of a system, region, or community to adapt to the effects of climate change. Adaptive capacity has an important role in addressing and minimizing vulnerability in an area. In order to understand the adaptive capacity of the watershed community, it is important to clarify the definition of the concept. In this context the 
intended pressure is a climate change whose symptoms can already be felt in the watershed (DAS) region. Vulnerability is the degree to which a system is vulnerable to and able to overcome the effects of climate change, including climate variability and extremes. [10].

Vulnerability is a function of character, distance and rate of climate change and open system variation, sensitivity and adaptive capacity . Vulnerability is a set of conditions and / or a result of circumstances (physical, social, economic and environmental factors) that adversely affect disaster prevention and mitigation efforts. [11].

If a hazard is a phenomenon or condition that is difficult to change then the relative vulnerability of society can be changed. Therefore, disaster risk reduction can be done by minimizing vulnerability. Vulnerability is associated with the human ability to protect the individual and the ability to cope with hazards/natural disasters without outside help. [10].

The complexity of the meaning of disaster vulnerability can then be defined and elaborated on the criteria of disaster vulnerability based on the impact characteristics generated on a particular object. Vulnerability, resilience, capacity, and responsiveness in emergency situations can be implemented at the individual, family, community and institutional levels . [12].

Some vulnerability formers include; number of persons, places where groups are in vulnerable positions and assets owned by a region. The exposure of climate change points to the presence of disasters in individuals, households, or social groups. Hence, susceptibility is often defined as a function of exposure risk or as a measure of coping ability. [13].

Thus, one measure of social susceptibility indicators departs from the understanding that social vulnerability refers to the exposure of a hazard or to the presence of stress conditions at the group or individual level due to exposure to a hazard. [14].

The level of vulnerability of the community is strongly influenced by access to natural resources and diversity of sources of income. Vulnerability may change at any time in the short or long run depending on how much the adaptation changes: the threat character, sensitivity, sensitivity, and recovery effort that results in quick results. Community resilience or also means the adaptation capacity of communities to defend their condition from the dangers of climate change. [14].

Therefore, the development of community adaptation is a way to be done in returning resilience as a result of climate change.

Strategies to improve people's resilience to climate-induced dangers with the aim of restoring or return their original state, can be done in various ways of adaptation such as through community based adaptation approaches through networking, or with local cultural and wisdom approaches. [15].

The selection of indicators on adaptive capacity parameters is based on the availability of data that can be processed up to the village boundaries, so that the resulting analysis can show and compare the adaptive capacity conditions of each village. with an explanation of adaptive capacity in the following numbers; Health Facilities(1); Disater Volunteers(2); Financial Services Providers(3); Posyandu Infrastrusture(4); EWS(5); Evacuation Line System(6); Household Heads who work by type of employment(7). [16];[17].

The analysis in the calculation of adaptive capacity parameters of the community created in the table as follows:

Table 2. Adaptive Capacity of Brantas Watershed Area

\begin{tabular}{|c|c|c|c|c|c|c|c|c|c|c|}
\hline No & $\begin{array}{c}\text { Brantas } \\
\text { Watershed }\end{array}$ & Sub-District & Villages & 1 & 2 & 3 & 4 & 5 & 6 & 7 \\
\hline 1 & \multirow[t]{4}{*}{ Hulu } & \multirow[t]{4}{*}{ Lowokwaru } & Dinoyo & 0.154 & 0.048 & 0.071 & 0.055 & 0.074 & 0.071 & 0.032 \\
\hline 2 & & & Jatimulyo & 0.026 & 0.071 & 0.071 & 0.055 & 0.074 & 0.071 & 0.057 \\
\hline 3 & & & T. Wulung & 0.077 & 0.071 & 0.071 & 0.094 & 0.074 & 0.071 & 0.051 \\
\hline 4 & & & Tlogomas & 0.077 & 0.071 & 0.107 & 0.063 & 0.074 & 0.080 & 0.039 \\
\hline 5 & \multirow[t]{4}{*}{ Tengah } & \multirow[t]{4}{*}{ Klojen } & Kiduldalem & 0.077 & 0.071 & 0.071 & 0.063 & 0.074 & 0.071 & 0.020 \\
\hline 6 & & & Oro Dowo & 0.179 & 0.071 & 0.071 & 0.055 & 0.074 & 0.0710 & 0.027 \\
\hline 7 & & & Samaan & 0.103 & 0.071 & 0.071 & 0.071 & 0.074 & $0.071 C$ & 0.040 \\
\hline 8 & & & Penanggungan & 0.103 & 0.057 & 0.071 & 0.063 & 0.074 & $0.063 c$ & 0.030 \\
\hline 9 & \multirow[t]{3}{*}{ Hilir } & K.Kandang & Kota Lama & 0.077 & 0.071 & 0.071 & 0.063 & 0.037 & $0.071 C$ & 0.138 \\
\hline 10 & & Blimbing & Jodipan & 0.103 & 0.062 & 0.071 & 0.063 & 0.074 & $0.071 C$ & 0.078 \\
\hline 11 & & & Polehan & 0.026 & 0.071 & 0.143 & 0.055 & 0.074 & $0.071 C$ & 0.085 \\
\hline
\end{tabular}

Source: Secondary data obtained [7],[8], [9].

The calculation of adaptive capacity parameters mentioned above is based on the condition of the region conducted the study compared to the total area of the region that entered into the study area. [18].

The result of weighting in secondary data analysis above then multiplied by the weight value of AHP quesioner result given to cadres or disaster volunteers that have been formed by BPBD at each village on each parameter in measuring adaptive capacity. [19]. 
This method is one that is be a requirement in using the AHP (apple to apple) method. The result of weights that has been obtained by filling out the questionnaire sheet by the cadres and disaster response volunteers created table as follows:

Table 3. Adaptive Capacity Capacity of Brantas Watershed

\begin{tabular}{clcc}
\hline No & Adaptive Capacity & Total & Score \\
\hline 1 & Health Facilities & 84 & 0.108 \\
2 & Disater Volunteers & 134 & 0.172 \\
3 & Financial Services Providers & 114 & 0.147 \\
4 & Posyandu Infrastrusture & 100 & 0.129 \\
5 & EWS & 53 & 0.068 \\
6 & Evacuation Line System & 36 & 0.046 \\
7 & Household Heads who worl & 257 & 0.330 \\
& by type of employment & & \\
$\quad \quad$ TOTAL SCORE & 778 & 1.000
\end{tabular}

Source: Secondary data obtained [7],[8], [9].

So as a follow-up of the calculation of adaptive capacity parameters, the weight of the result of questioner assessment with AHP method (primary data gain result) is multiplied by the result of calculation of secondary data, with an explanation of adaptive capacity in the following numbers; Health Facilities(1); Disater Volunteers(2); Financial Services Providers(3); Posyandu Infrastrusture(4); EWS(5); Evacuation Line System(6); Household Heads who work by type of employment(7).

Finally, the result of weight calculation by multiplying the weight of the result of quesioner filling can be labeled as follows:

Table 4. Weight of adaptive capacity of each village

\begin{tabular}{|c|c|c|c|c|c|c|c|c|c|c|}
\hline No & $\begin{array}{c}\text { Brantas } \\
\text { Watershed }\end{array}$ & Sub-District & Villages & 1 & 2 & 3 & 4 & 5 & 6 & 7 \\
\hline 1 & Hulu & Lowokwaru & Dinoyo & 0.4520 & $0.354 C$ & 0.286 & 0.2580 & 0.251 & 0.129 & 0.664 \\
\hline 2 & & & Jatimulyo & 0.2160 & $0.708 \mathrm{C}$ & 0.286 & 0.2580 & 0.251 & 0.129 & 0.664 \\
\hline 3 & & & T. Wulung & 0.3240 & $0.708 \mathrm{C}$ & 0.286 & 0.5160 & 0.251 & 0.129 & 0.664 \\
\hline 4 & & & Tlogomas & 0.3240 & $0.708 \mathrm{C}$ & 0.286 & 0.2580 & 0.251 & 0.168 & 0.664 \\
\hline 5 & Tengah & Klojen & Kiduldalem & 0.3240 & $0.708 \mathrm{C}$ & 0.286 & 0.2580 & 0.251 & 0.129 & 0.664 \\
\hline 6 & & & Oro Dowo & 0.4320 & $0.708 \mathrm{C}$ & 0.286 & 0.2580 & 0.251 & 0.129 & 0.664 \\
\hline 7 & & & Samaan & 0.3390 & 0.708 & 0.286 & 0.3870 & 0.251 & 0.129 & 0.664 \\
\hline 8 & & & Penanggungan & 0.3390 & D.354c & 0.286 & 0.2580 & 0.251 & 0.084 & 0.664 \\
\hline 9 & Hilir & K.Kandang & Kota Lama & 0.2260 & $0.708 \mathrm{C}$ & 0.286 & 0.5160 & 0.251 & 0.129 & 1.328 \\
\hline 10 & & Blimbing & Jodipan & 0.3390 & $0.531 \mathrm{C}$ & & & & & 0.996 \\
\hline 11 & & & Polehan & 0.2260 & $0.708 c$ & 0.572 & 0.2580 & 0.251 & 0.129 & 0.996 \\
\hline
\end{tabular}

Source: Secondary data obtained[7],[8], [9]

The results of the analysis obtained from all villages compared with adaptive capacity parameters, then added horizontally to get the value of each village and weighted with a value between 0-5, it will obtain weight for adaptive capacity in the table as follows:

Table 5. Weight of village adaptive capacity

\begin{tabular}{ccccc}
\hline No & Brantas Watershed & Sub-District & Villages & Weight \\
\hline 1 & Hulu/Upstrem & Lowokwaru & Dinoyo & 2 \\
2 & & & Jatimulyo & 2 \\
3 & & & T. Wulung & 3 \\
4 & & Tlogomas & 3 \\
5 & Tengah/Central & \multirow{2}{*}{ Klojen } & Kiduldalem & 3 \\
6 & & & Oro Dowo & 3 \\
7 & & & Samaan & 3 \\
8 & & & Penanggungan & 1
\end{tabular}

$\begin{array}{ccccc}9 & \text { Hilir/Downstream } & \text { K.Kandang } & \text { Kota Lama } & 4 \\ 10 & \text { Blimbing } & \text { Jodipan } & 3 \\ 11 & & \text { Polehan } & 4\end{array}$

Source: Secondary data obtained[7],[8], [9].

From the results of the adaptive capacity weighting table of the village area as a basis for the manufacture of spatial maps. [20]. Weighting values can be explained as follows:

- weight 4 : very high

- weight 3 : high

- weight 2 : medium

- weight 1 : low

After the weight value of each village is known then in overlay into the spatial map so that obtained the distribution of adaptive capacity map of Brantas watershed of Malang City as follows[20]:

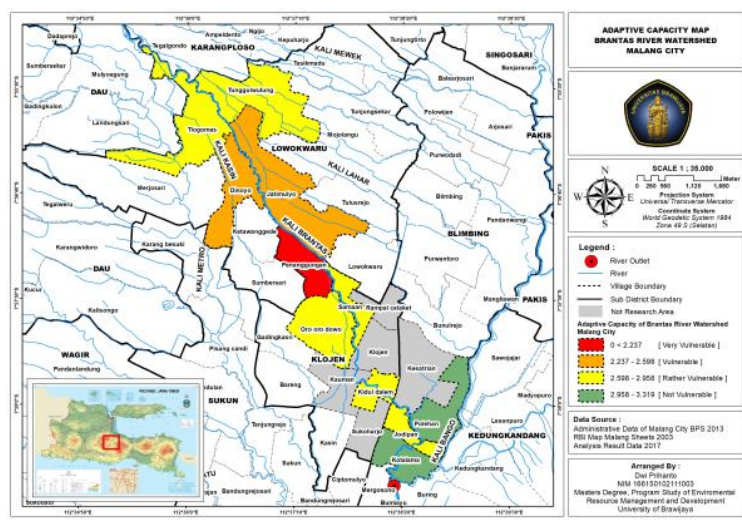

Picture 1. Map of Adaptive Capacity of Brantas Watershed Area Malang city

\section{CONCLUSION}

Kota Lama and Polehan are villages with adaptive capacity in low category. Kota Lama and Polehan is also a village downstream of Brantas watershed of Malang City. Elements that make adaptation capacity low include the availability of a minimal early warning system (EWS) compared with the number of residents who are on the river banks Brantas watershed, including the number of evacuation routes are very small.

The number of resilient volunteers is only 1015 people, whereas the population is 650 households.Likewise the number of banking institutions engaged in micro business community groups vulnerable to disasters is very limited.

Methods and analysis used in this adaptive capacity study using seven criteria of research indicator, since data obtained from local or regional organizations are very limited so that it will affect the results of each study village 


\section{SUGGESTION}

Malang City Government must conduct structural mitigation by building retaining wall in areas prone to landslide disaster, improving sustainable drainage system; strengthening weather and climate information systems by developing weather and climate information technologies, developing an early warning system (EWS) for landslides and floods, improving the conservation of water resources by planting trees and bamboo, developing absorption wells, and making biopore holes.

While non-structural can be done by increasing the capacity of volunteer cadres and volunteers, mapping of potential areas and vulnerable to landslide hazards and floods make operational standards of disaster emergency response procedures, establishing disaster risk reduction forums for rural and urban areas, reviewing related to spatial planning Brantas watershed of Malang City based on climate and disaster.

\section{ACKNOWLEDGEMENTS}

My greatest thanks to my father and motherin-law, my wife and my two children who always give the spirit, motivation and encouragement completely and always pray. Similarly, USAIDAPIK colleagues who always take the time to discuss and share information related to climate change adaptation and disaster risk reduction. Friends of Malang City Government partners who always support in the ease of obtaining the completeness of secondary data for community vulnerability research.

As well as fellow students of the Master Program of Environmental and Development Resources Management, Brawijaya University Malang with a passion for discussion and some parties who have helped that can not be mentioned one by one until the end of the perfection of this paper.

\section{REFERENCES}

[1]. Nur miladan. (2009) study of the vulnerability of coastal areas of Semarang city to climate change. Summary of a graduate program of master's thesis in the construction of the Diponegoro university and regional universities. Semarang.

[2]. BNPB. (2010) map of indices of socioeconomic vulnerability in Indonesia.

[3]. Ministry of the environment and forestry. (2014) information system index vulnerability data. Directorate of adaptation to climate change. Jakarta.

[4]. Astuti, A.M. 2008. The Effect of Water Fraction of Stellaria sp. on the Content of TNF- $\alpha$ in Mice (Mus musculus BALB-C). Thesis. Department of Biology. University of Brawijaya. Malang. (Thesis)

[5]. Eko subekti. Ir. Dipl. He. (29 juli 2009). Work general Department. Water resources management of brantas river area. National seminar on regional infrastructure technology applications. Its. Head of bbws brantas. Surabaya.

[6]. Bappeda Malang City. (2014) preparation of master plan of drinking water system of poor city.

[7]. Central Bureau of Statistics. 2014. Potential Village Data (PODES). East Java

[8]. BPBD Malang City. 2016. Disaster Recapitulation of Malang City.

[9]. Central Bureau of Statistics of Malang City . 2017. "Kecamatan Dalam Angka".

[10]. Directorate of adaptation to climate change. (2016) vulnerability and adaptation to climate change. Klhk.

[11]. BNPB. 2010. Socioeconomic Vulnerability Index Map In Indonesia. Jakarta

[12]. Efendi muchtar. (2012) assessment of the community's vulnerability to climate change and watershed based adaptation strategies (case study: sub das upstream). Magister program of environmental science of Diponegoro University's postgraduate program.

[13]. The World Bank. 2009. World Development Report 2010: Development and Climate Change. Washington DC: The World Bank.

[14]. Adger, W., Brooks, N., Kelly, M., Bentham, G.,Agnew, M., and Eriksen, S., (2004): New indicators of vulnerability and adaptive capacity; Tyndall Centre, Technical Report.

[15]. Dean, R.G. 1990. Freak waves: A possible explanation. p. 1-65. In Torum, A., O.T. Gudmestad (eds). Water wave kinetics. CRC Press. New York. (Chapter in a Book)

[16]. Eko pujiono and retno setyowati. (2015) assessment of vulnerability of water resources to climate variability in das aesesa. Island flores. East Nusa Tenggara. Kupang forest research center.

[17]. Ida nurul hidayati. Suryanto. (april 2015). the effects of climate change on agricultural production and adaptation strategies on drought-prone land. 
Economics and Business Faculty. Sebelas Maret University.

[18]. Nugroho, Kharisma,dkk. 2011.CommunityBased Disaster Risk Reduction in Indonesia:Movement, Institutionalization and Sustainability. Jakarta: Publisher.

[19]. Ministry of the environment and forestry Republic of. (2016) regulation of minister of environment and forestry republic indonesia number p.33/menlhk/setjen/ kum.1/3/2016. About the guidelines for the preparation of climate change adaptation action.

[20]. Ministry of Public Works. (2010). Water resources management pattern of Brantas river area. Ministerial decree. Jakarta.

[21]. President of the republic of indonesia. (2008) Indonesia number 42 of 2008. About the management of water resources. Jakarta. 